\title{
Joewood (Jacquinia keyensis): Identification and Uses ${ }^{1}$
}

\author{
Stephen H. Brown, Marc S. Frank, and Andrew K. Koeser²
}

Family: Primulaceae (formerly in Theophrastaceae)

Common Names: Joewood; barbasco; cudjo wood; ironwood; joebush; washwood

Native Distribution: South Florida; Bahamas; Cayman Islands; Cuba; Haiti; Jamaica

USDA Zone: $10 \mathrm{~A}-12 \mathrm{~B}\left(27^{\circ} \mathrm{F}\right.$ minimum $)$

Plant Type: Shrub or small tree

Growth Rate: Slow

Typical Dimensions: $8 \mathrm{ft}$. tall x $12 \mathrm{ft}$. wide

Leaf Persistence: Evergreen

Leaf Type: Simple, entire

Flowering Months: Sporadic but heaviest between June and November

Flower Color: White; ivory

Fruit Color: Ivory; orange-red; yellow

Light Requirements: Full sun to light shade

Soil Tolerances: Clay; sand; loam; acidic; alkaline; brackish; well-drained; rarely inundated
Drought Tolerance: High

Salt Tolerance: High

Wind Tolerance: High

Nutritional Requirements: Low

Propagation: Seeds; cuttings

IFAS Assessment: Not evaluated (native)

Human Hazards: Potentially poisonous but toxic compound undetermined

\section{Major Insect and Disease Problems: None}

Uses: Specimen; small flowering tree; coastal locations; container; streetscapes; wildlife host

Table 1. Nomenclature for Jacquinia keyensis

\begin{tabular}{|l|l|}
\hline Kingdom & Plantae \\
\hline Phylum & Tracheophyta \\
\hline Order & Ericales \\
\hline Family & Primulaceae \\
\hline Genus & Jacquinia \\
\hline Species & Jacquinia keyensis Mez \\
\hline Varieties & None \\
\hline
\end{tabular}

1. This document is ENH1284, one of a series of the Environmental Horticulture Department, UF/IFAS Extension. Original publication date January 2018. Visit the EDIS website at http://edis.ifas.ufl.edu.

2. Stephen H. Brown, horticulture agent, UF/IFAS Extension Lee County, Fort Myers, FL 33916; Marc S. Frank, Extension botanist, UF/IFAS Plant Identification and Information Service, University of Florida Herbarium, Gainesville, FL 32611; and Andrew K. Koeser, assistant professor, UF/IFAS Gulf Coast Research and Education Center, Wimauma, FL 33598. 


\section{Florida Distribution}

Joewood (Jacquinia keyensis) is most common in the Florida Keys (Monroe County), where it occurs in coastal scrubs, on shell mounds, and is associated with rockland hammocks and dry sites. It prefers transition areas between coastal thickets and maritime hammocks. Joewood is also found on the northern shoreline of Florida Bay in Monroe County, in the Long Pine Key region of Everglades National Park, in Miami-Dade County, and on a few barrier islands in Lee and Charlotte Counties. It is listed as a threatened species by the state of Florida due to habitat loss and the rapid decline in the number of plants within the state. Population losses have not sufficiently decreased the number of plants to cause them to be endangered or listed as threatened. Joewood is best protected and preserved on naturally occurring sites.

In 1989, the city of Sanibel in Lee County, at the recommendation of its vegetation committee, declared the joewood to be its "city plant" in hopes that the declaration would increase respect for this native species and enhance its protection and distribution on the island.

\section{Growth Habit}

Joewood is a very slow growing, long-lived shrub or small tree. Seedlings under nursery conditions initially grow about six inches a year and are about three feet when six or seven years old. Plants found in the wild are seldom above 12 feet tall.

Joewood may be single- or multi-trunked with as many as seven smaller trunks sometimes emerging from a single main trunk close to the ground. Thus, large, multi-trunked specimens may be mistaken as a clump of tightly grown shrubs or trees. Even old joewood trees remain relatively small. One of the larger specimens identified by the primary author is an 18-foot-tall specimen on Sanibel Island. The tree has five trunks, the largest of which is 11 inches in diameter. It has been designated by the Florida Forest Service as the state's champion Joewood tree.

The trunks of joewood are smooth and gray at first, later becoming mottled by lichens. The interior wood lacks distinct growth rings. The twigs are gray when young. The plant is evergreen, and growth can occur at any time of the year. Much of the attraction of the plant is in its shape. No central leader develops. Instead, joewood produces numerous short, rigid branches, giving the plant a compact rounded crown and a distinctive appearance. If grown in full sun with plenty of room to spread, the canopy of joewood will be wider than tall. Multi-trunked plants are significantly wider than single-trunked specimens of similar heights.

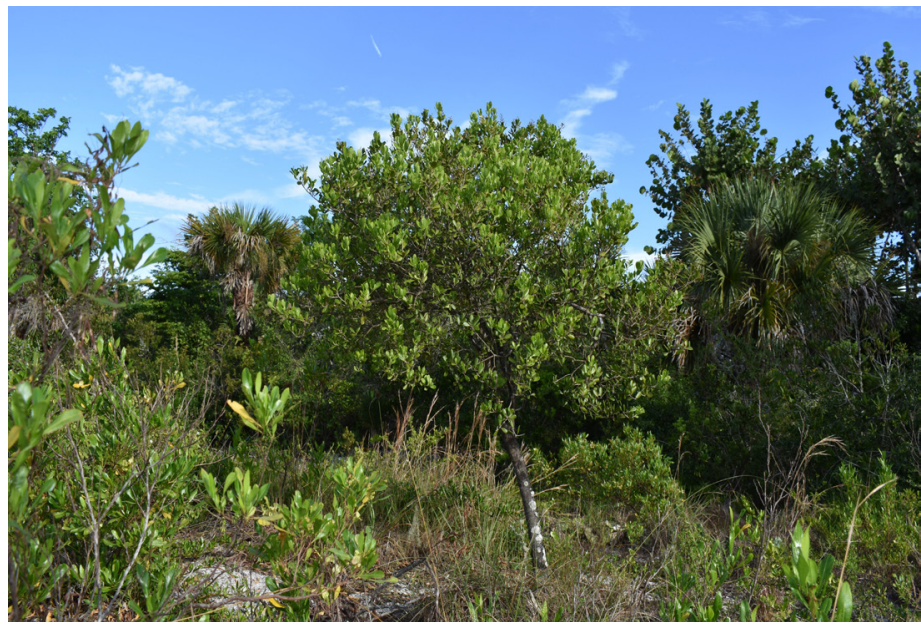

Figure 1. A single-trunked, $6.25 \mathrm{ft}$. $x 7.5 \mathrm{ft}$. joewood specimen in late October. Credits: Stephen H. Brown, UF/IFAS

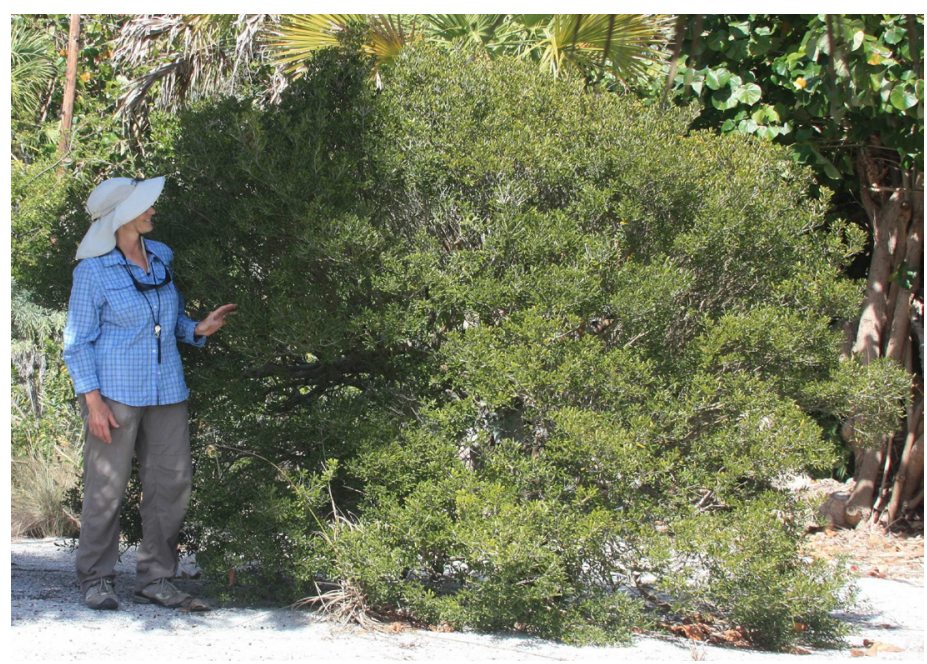

Figure 2. A multi-trunked, $8.0 \mathrm{ft}$. $\times 12 \mathrm{ft}$., ornamental specimen in late March. Credits: Stephen H. Brown, UF/IFAS

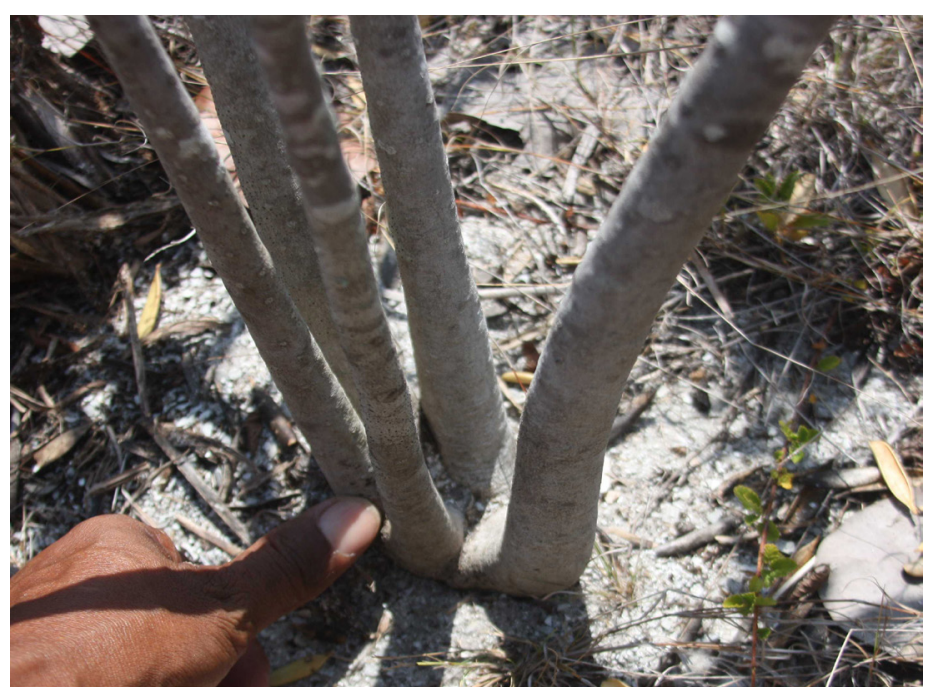

Figure 3. Five connected trunks of a small plant just above the soil's surface. Credits: Stephen H. Brown, UF/IFAS 


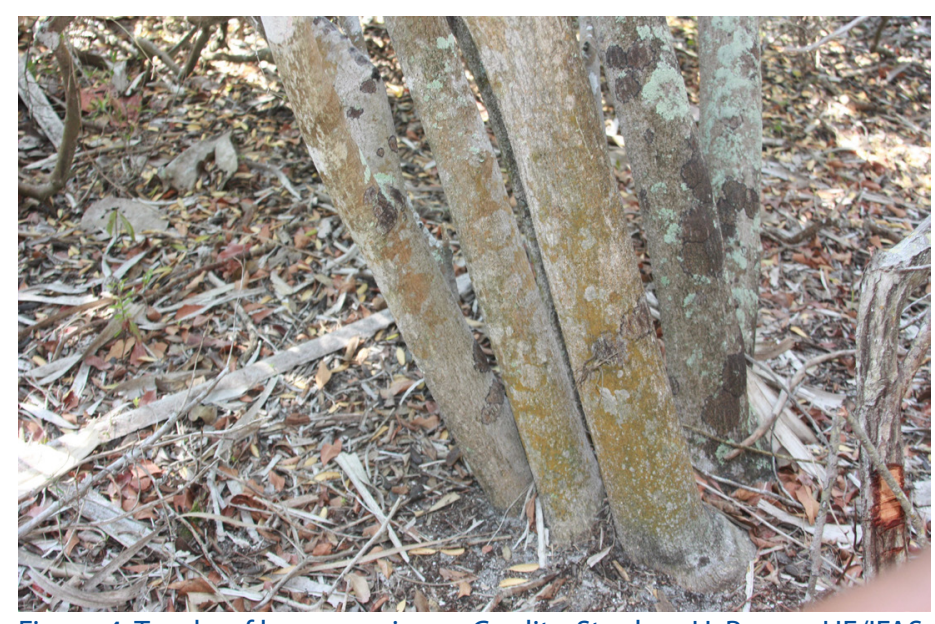

Figure 4. Trunks of large specimen. Credits: Stephen H. Brown, UF/IFAS

\section{Leaves}

Leaves are simple, alternately, and spirally arranged, sometimes with very short internodes that may give a false appearance of being whorled. The false whorled characteristic is more common among other Jacquinia species and is referred to as pseudoverticillate. Leaves are yellow-green in color shortly after emerging and remain mostly upright. The leaf blades are stiff, shiny, leathery, and mostly recurved slightly to strongly curved downward. They have inconspicuous venation and margins that are entire and revolute (rolled under). The shape of the blades varies from broadly to narrowly obovate to broadly elliptic. Leaf bases are attenuate (tapering towards a very short petiole). The apices are rounded to retuse (shallowly notched), often with a mucro (short sharp abrupt point formed by extension of the midrib). The blades are approximately 1.5 to 2 inches long and 0.5 inch wide, and the petioles mostly 0.2 inches in length.

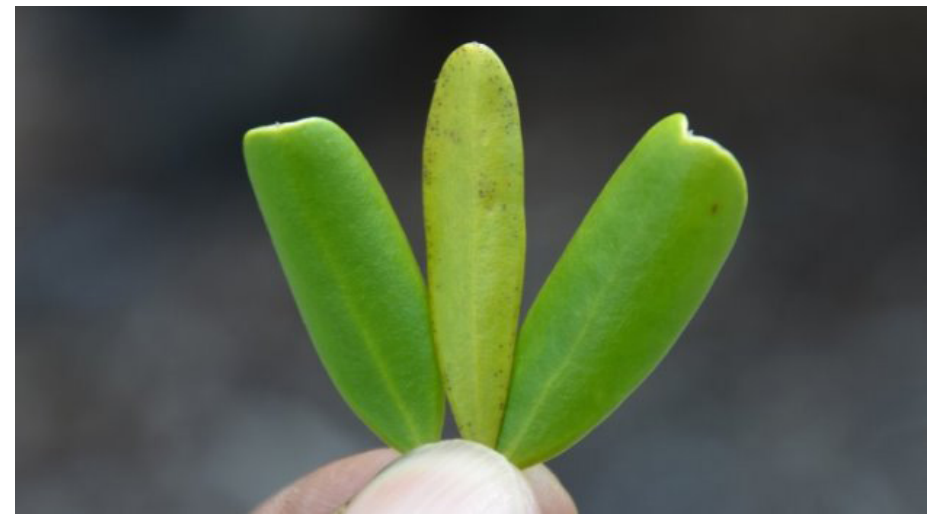

Figure 5. Narrowly obovate outer leaves with broadly elliptic leaf (center), depicting (left to right) retuse, rounded, and mucronate leaf apices. Credits: Stephen H. Brown, UF/IFAS

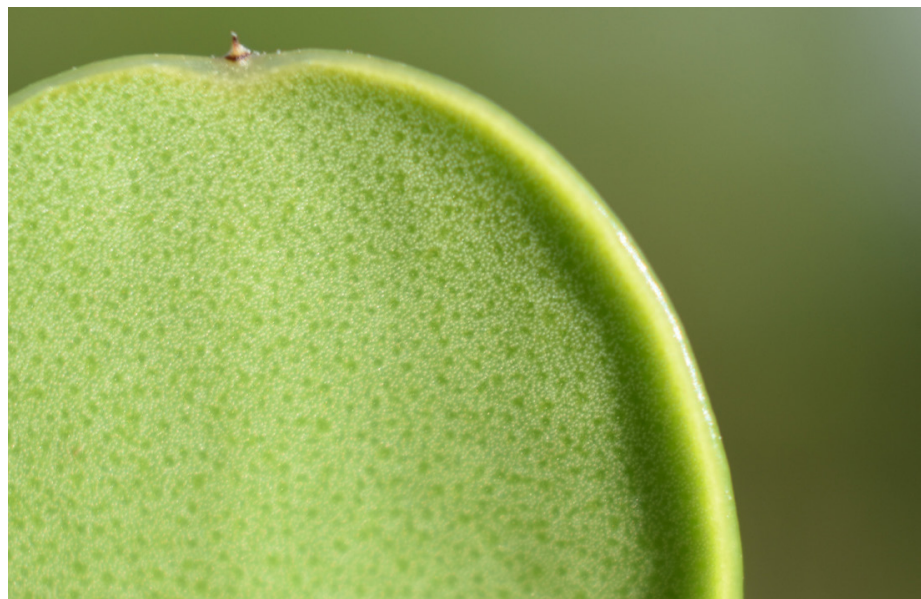

Figure 6. Revolute leaf margin on leaf underside and mucro at leaf apex. Credits: Stephen H. Brown, UF/IFAS

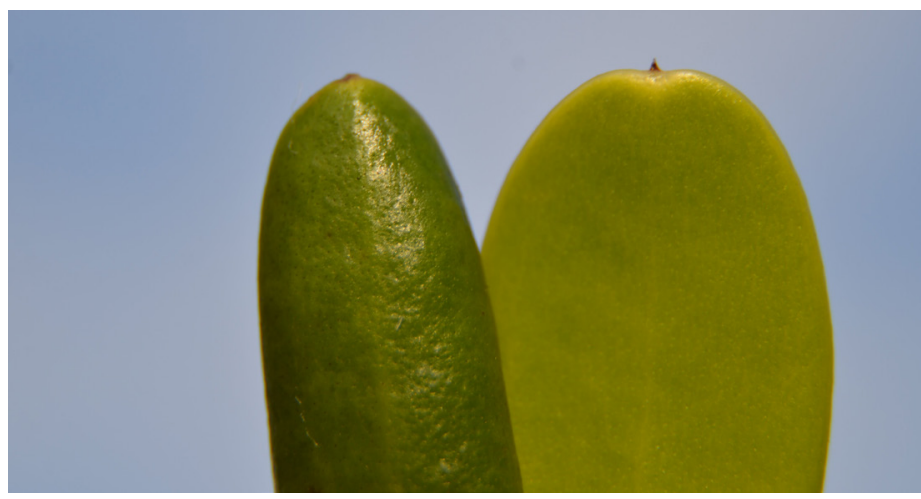

Figure 7. Left: elliptical recurved leaf with rounded apex and a broken mucro. Right: narrowly obovate leaf with a retuse apex and an intact mucro. Credits: Stephen H. Brown, UF/IFAS

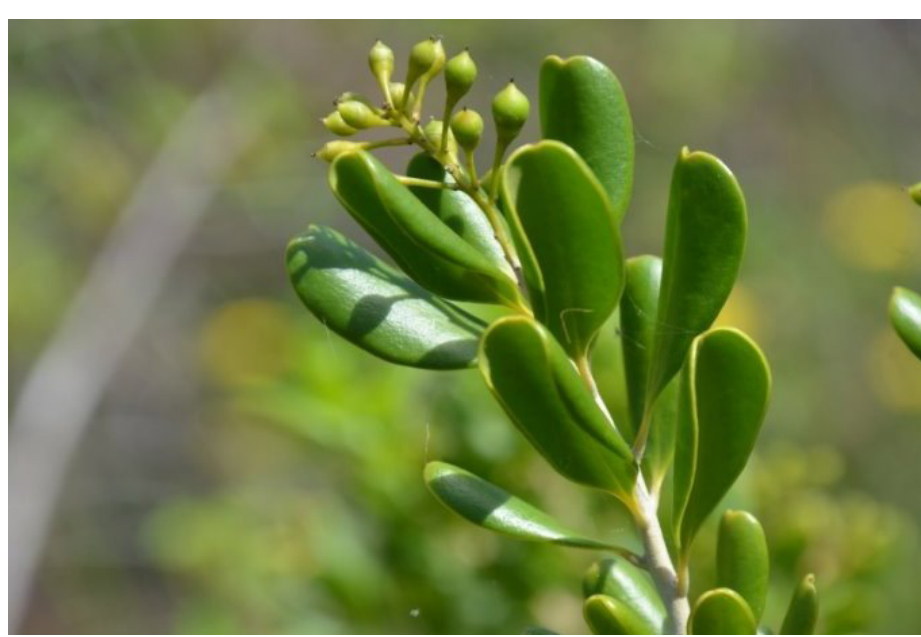

Figure 8. Terminal raceme with fruit and stem showing alternate, spiraled leaf arrangement of simple recurved leaves with varied leaf shapes and apices. Credits: Stephen H. Brown, UF/IFAS 


\section{Flowers, Pollination, and Flowering}

Flowers appear in conspicuous terminal racemes and are especially fragrant. The aroma is reminiscent of jasmine and is said to be unsurpassed by any other native in Florida's natural plant communities.

Racemes are up to three inches long. At the base of each flower is a short, green calyx, with five, indistinct, rounded lobes. There are five white or ivory colored petals which spread widely when the flowers are fully mature. The petals alternate with five shorter, petal-like staminodes (sterile stamens) of the same color, making it appear that each flower has ten petals. Five functional stamens lie opposite the five petals.

The flowers have both male and female reproductive parts (stamens and pistils) present on the same flower. However, dichogamy is pronounced, with the stamens and pistils maturing at different times to promote outcrossing. Joewood is protogynous; hence, female parts of flowers develop first and the male parts produce pollen after the stigmas of the same flower are receptive. Insect pollinators (thought to be bees and wasps seeking nectar) are attracted to the sweet-scented flowers.

Plants may flower at any time of year, but most commonly do so from mid-spring to early fall. Some individual plants or groups of plants may flower more abundantly than others. It is not uncommon for flowers and fruits to be present on a plant simultaneously.

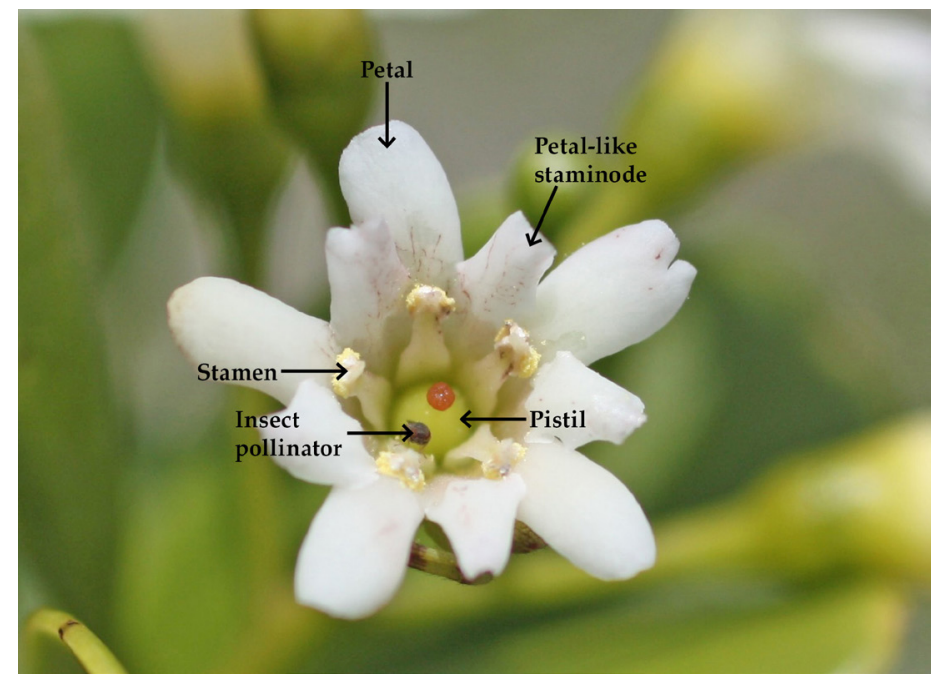

Figure 9. Flower parts and pollinating insect. Credits: Stephen $\mathrm{H}$. Brown, UF/IFAS

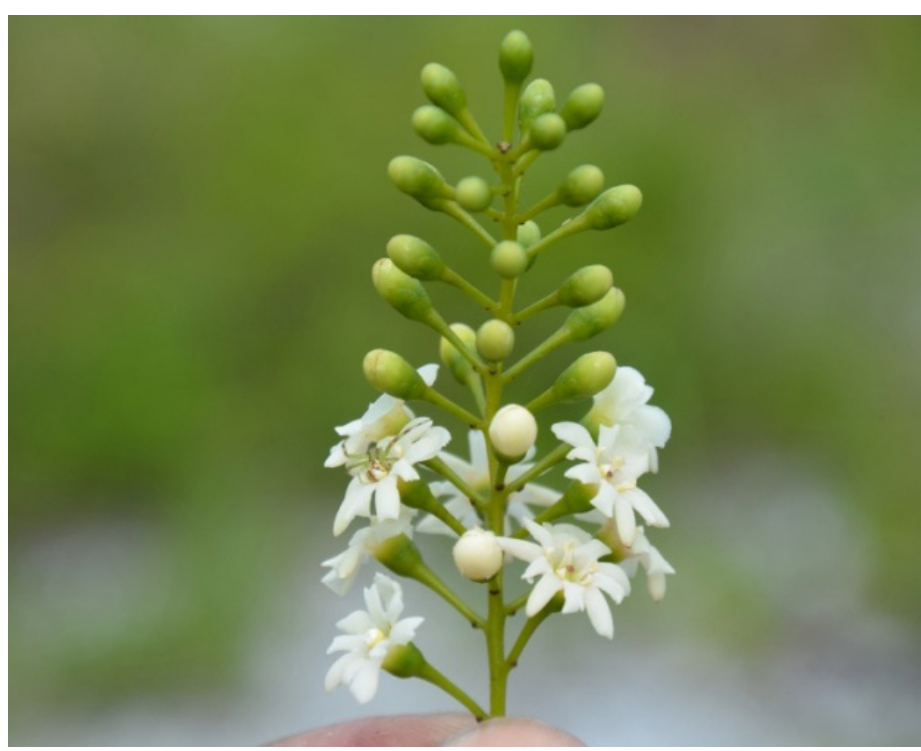

Figure 10. Terminal raceme of joewood. Credits: Stephen H. Brown, UF/ IFAS

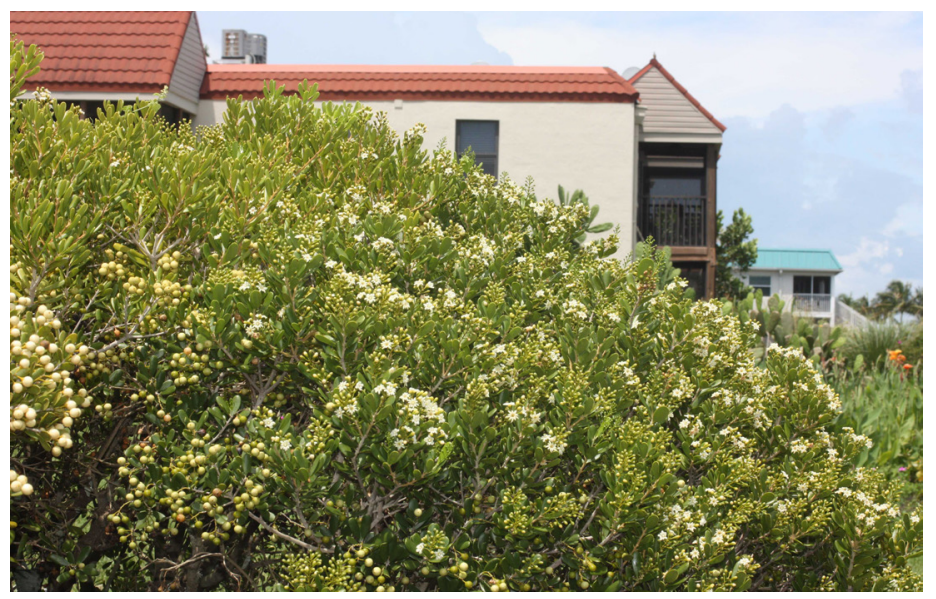

Figure 11. Flowering and fruiting of joewood in early July. Credits: Stephen H. Brown, UF/IFAS

\section{Fruits and Fruiting}

With the female reproductive organs of joewood maturing before the male reproductive organs, a small green berry is often seen developing in the center of the flower while petals and functional stamens are still present. After pollination, the petals of the flowers fall, and the numerous green pistils (immature berries) remain on the terminal racemes. Fruit clusters are generally pendent, though they can be upright when supported by lower leaves. The fruits are round, smooth, hard-coated berries with the style persistent at the tip. They are about 0.35 inches in diameter and are connected to a pedicel of the same approximate length. On Sanibel Island, mature fruits are ivory-colored, but they are typically described elsewhere as being goldenorange to orange-red in color. The interior of the fruit has a sticky, gelatinous pulp containing several small embedded seeds that are fused together when the fruits are completely dried. White-crowned pigeons and other birds feed on the 
fruits of joewood, and the plant provides significant cover for wildlife.

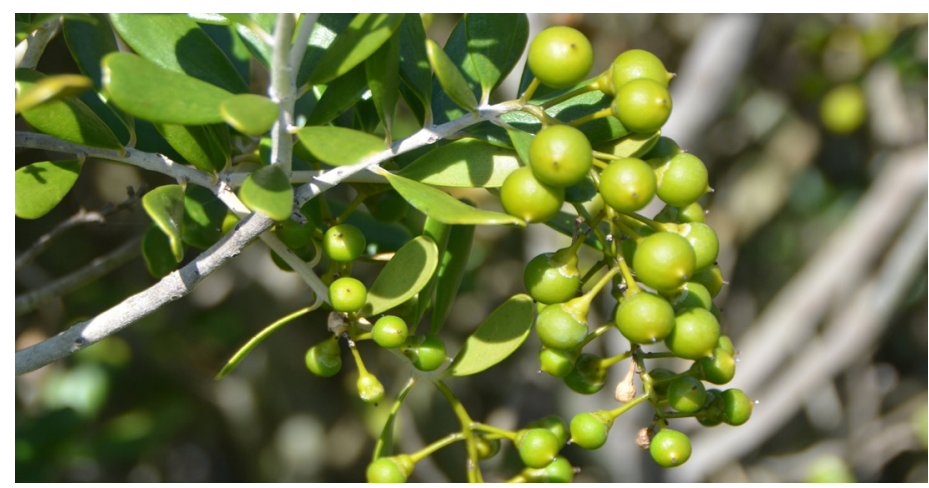

Figure 12. Immature green berries in terminal racemes. Credits: Stephen H. Brown, UF/IFAS

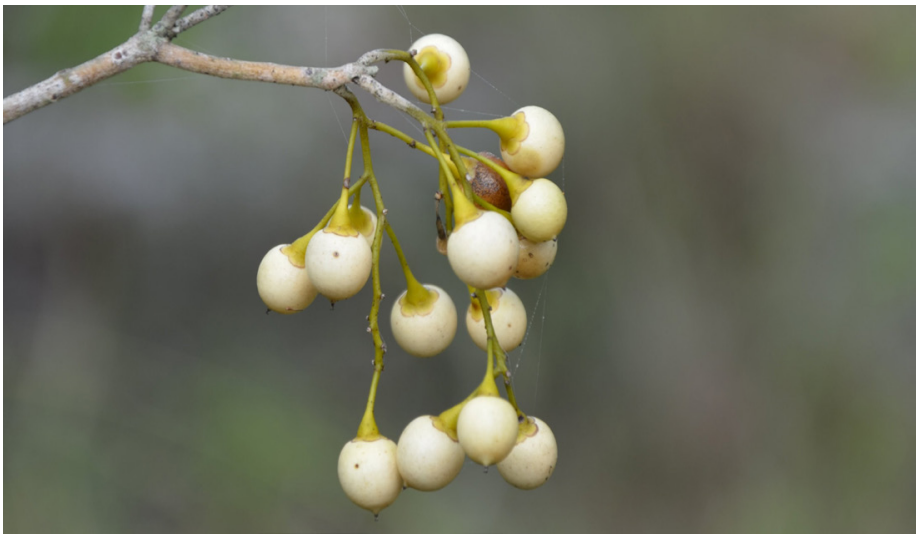

Figure 13. Mature ivory-colored berries. Credits: Stephen H. Brown, UF/IFAS

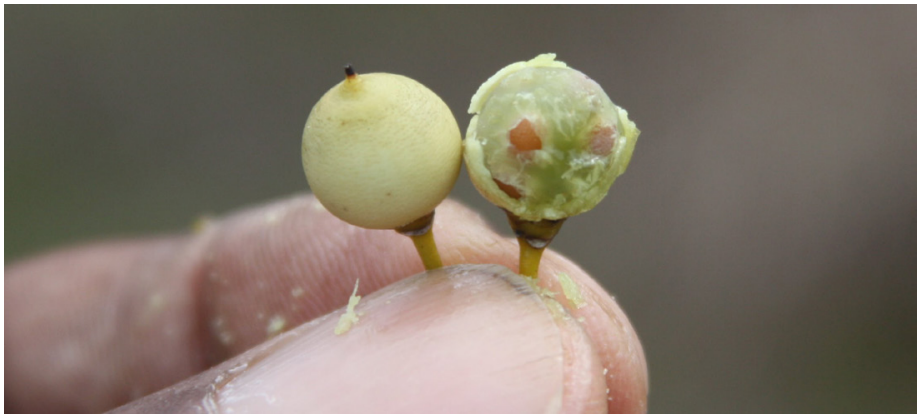

Figure 14. Ripe fruit showing intact persistent style at apex and an opened berry exposing the gelatinous pulp and embedded seeds. Credits: Stephen H. Brown, UF/IFAS

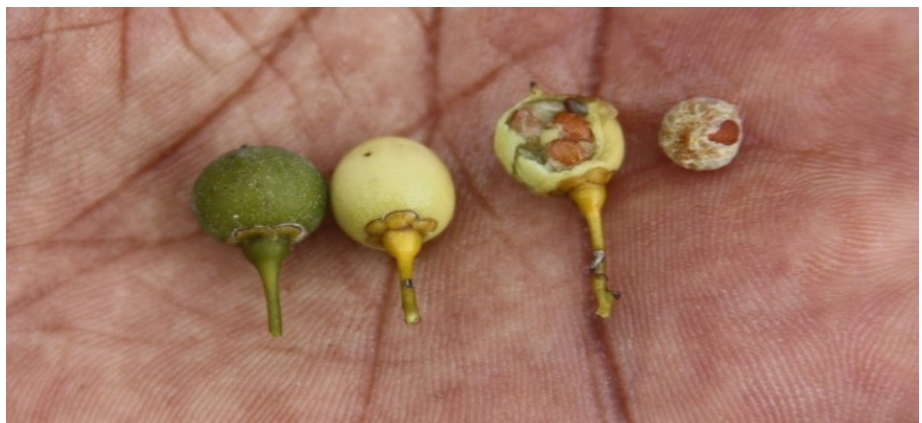

Figure 15. From left to right: unripe and mature intact fruits, opened (showing brown seeds) pulpy fruit, and dried fruit. Credits: Stephen $\mathrm{H}$. Brown, UF/IFAS

\section{Landscaping}

Joewood makes a good specimen plant tolerant of sandy, high-pH soils, salt air, and short periods of salt water intrusion. It adapts to partial shade, but should be planted in full sun in order to develop a fully-rounded crown. Container plants can be planted at any time of the year.

After planting, water it frequently for several weeks for establishment. Once established, it can withstand heat, drought, and severe wind. It rarely, if ever, needs pruning. Plant development is slow but adequate fertilizer applications and routine irrigation in the dry season should accelerate growth.

\section{Best Ways to Identify Joewood}

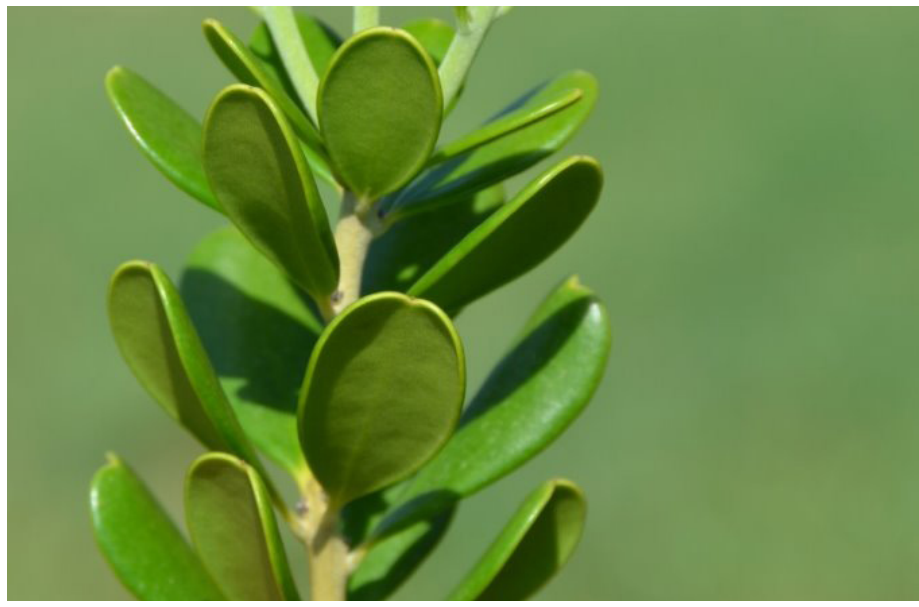

Figure 16. Simple, recurved leaves with a revolute margin and varied leaf shapes, and apices arranged in an alternate, spiraled pattern with short internodes. Credits: Stephen H. Brown, UF/IFAS

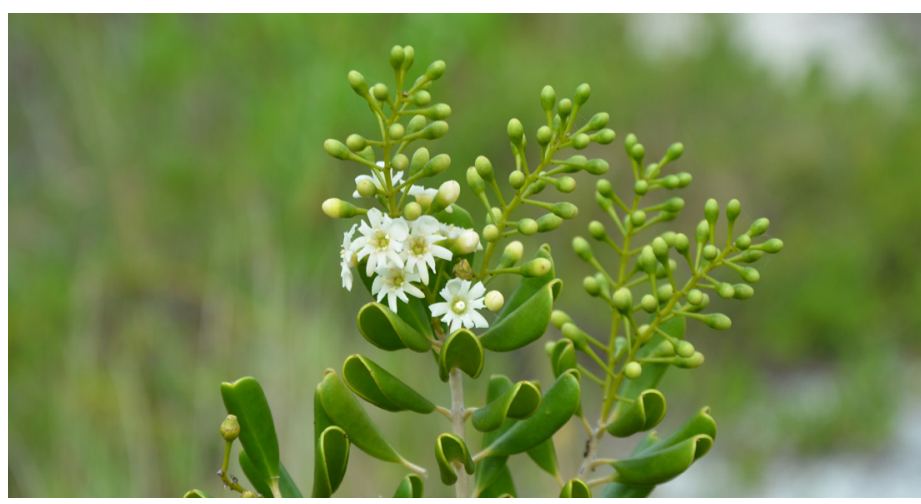

Figure 17. Unbranched racemes on the terminal branches with small, white or ivory-colored fragrant flowers appearing to have petals of alternating lengths. Credits: Stephen H. Brown, UF/IFAS 


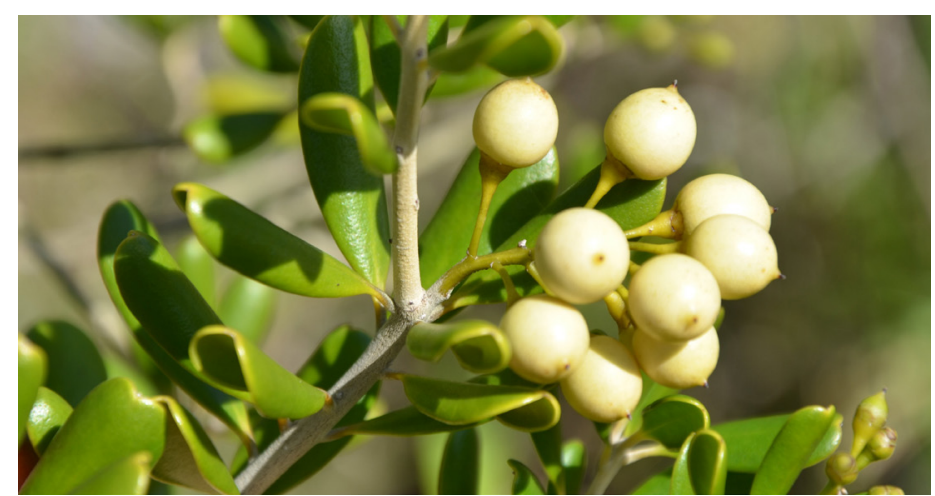

Figure 18. Small, firm, rounded berries with a very short persistent style at the tip, arranged in unbranched racemes on the terminal branches. Credit: Stephen H. Brown, UF/IFAS

\section{Comparison of Jacquinia keyensis Mez and Jacquinia arborea Vahl}

Jacquinia arborea (previously known as Jacquinia armillaris var. arborea) braceletwood is a non-native relative of joewood. Identification of these species is important, as braceletwood has naturalized in Southern Florida and has been identified as an invasive plant species by the Florida Keys Invasive Species Task Force.

When compared side by side, these two species are readily distinguished. The leaf blades of the braceletwood are larger and not as leathery in appearance. They are commonly 3.0-5.0 inches long and about 1.5 inches wide. The petioles are approximately 0.3 inches long. In braceletwood, the internodes are extremely short, resulting in a strongly pseudoverticillate leaf arrangement; in joewood, the internodes are slightly longer, so the leaves are only weakly pseudoverticillate. The leaf margins of braceletwood may be flat or slightly revolute (rolled under), but are never strongly revolute, as often seen in joewood. Both species have highly fragrant flowers. Joewoods are found to have mostly ivory-colored berries in Lee County, with reports of otherwise golden-orange, orange-red, and yellow fruits. The berries of braceletwood are approximately the same size as joewood, but fruits are consistently orange-red or red.

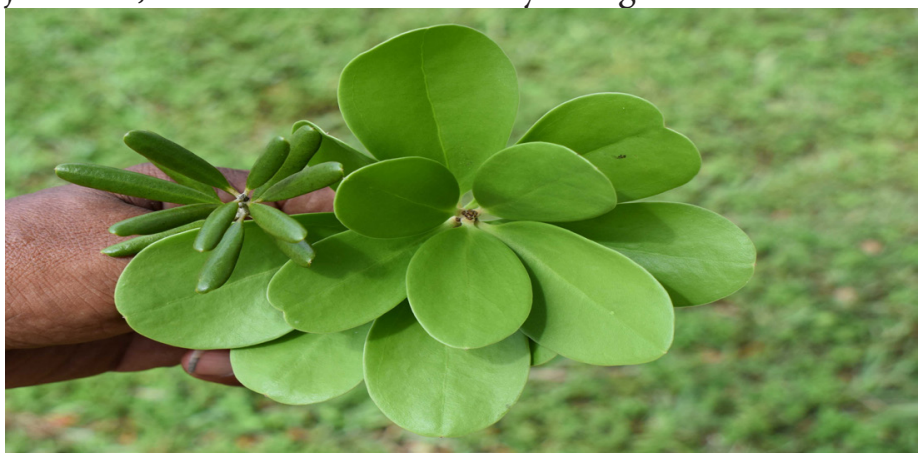

Figure 19. Left: terminal growth of joewood with cupped leaves. Right: terminal growth of braceletwood with larger, flattened leaves.

Credits: Stephen H. Brown, UF/IFAS

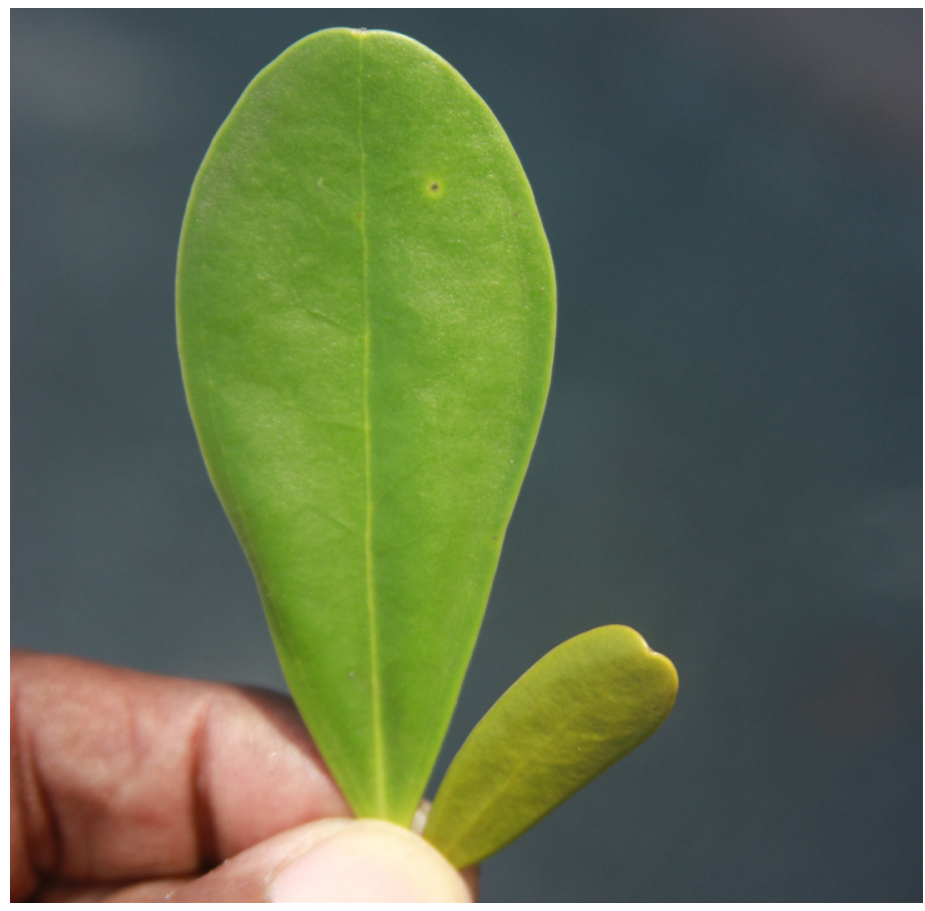

Figure 20. Leaves of braceletwoods are usually 2-3 times the length of joewood. Credits: Stephen H. Brown, UF/IFAS

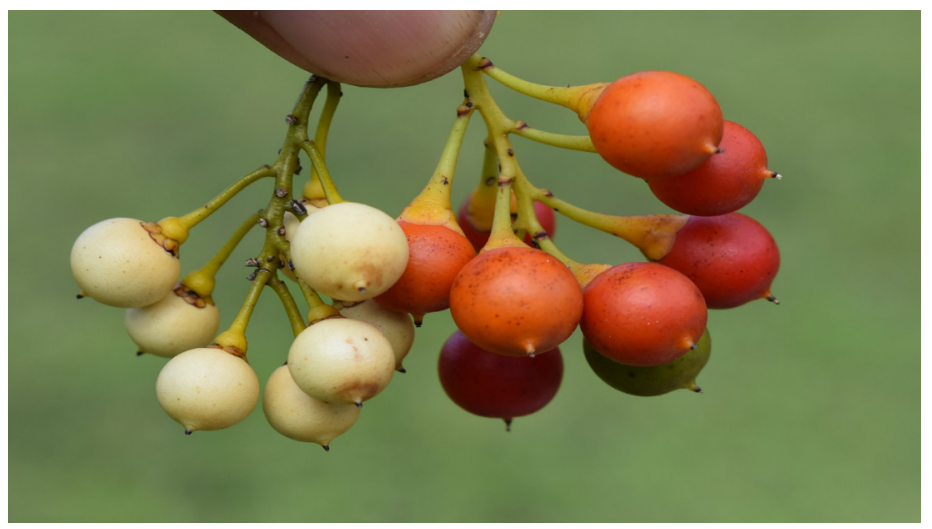

Figure 21. Left: ivory-colored berries of joewood. Right: slightly larger red berries of braceletwood. Credits: Stephen H. Brown, UF/IFAS

\section{List of Botanical Terms}

Apex (pl. apices): The point of a leaf furthest from the petiole.

Attenuate: Gradually tapering at the base or at the tip.

Berry: A fleshy fruit with many seeds developing from a single pistil.

Calyx (pl. calyces, calyxes): Group or cluster of modified leaves enclosing a flower bud, each segment being a sepal.

Dichogamous: With the pistils and stamens maturing at different times to prevent self-fertilization. 
Elliptic: A leaf blade broadest at the middle and narrower at two equal ends.

Entire: Complete, not toothed, notched, or divided, with smooth margins.

Internode: The portion of a stem between two nodes.

Margin: The edge, as in the edge of a leaf blade.

Mucro: A short, sharp, abrupt terminal point.

Obovate: Widest above the center. The opposite of ovate.

Pedicel: The stalk of a single flower.

Petal: An individual segment of the corolla, variously colored, seldom green.

Pistil: The female organ of a flower consisting of stigma, style and ovary.

Pseudoverticillate: Having very close internodes, thus giving the appearance of whorled leaves.

Petiole: The stalk of a leaf.

Protogyny: The female parts of a flower developing before the male parts.

Raceme: An unbranched inflorescence with stalked flowers on an elongated axis with flowers opening in succession towards the apex.

Recurved: Curved backward.

Retuse: Shallowly notched at the apex.

Revolute: With leaf margins rolled downward toward the underside.

Stamen: The male organ of a flower consisting of an anther and a filament.

Staminodes: Sterile stamens.

Stigma: The apex of a pistil (female part) that is receptive to pollen grains.

Style: The usually narrow portion of the pistil between the stigma and the ovary.

\section{References}

Broschat, T.K. and A.W. Meerow, 2001. Reference Guide to Florida Landscape Plants. Hollywood, Florida: Betrock Information System, Inc.

Farnsworth, Steve. "Cold Hardiness Report on Tropical Native Plants," The Palmetto, 1985. Orlando, Florida: Florida Native Plant Society. 5(3):12.

Gann, G.D., M.E. Adbo, J.W. Gann, G.D. Gann, Sr., S.W. Woodmansee, K.A. Bradley, E. Grahl and K.N. Hines. 2016. "Joewood: Jacquinia keyensis." Natives For Your Neighborhood: A program of the Institute for Regional Conservation, Delray Beach, Florida. http://www.regionalconservation.org/beta/nfyn/plantdetail.asp?tx=Jacqkeye

Flora of North America Editorial Committee, eds. 1993+. Flora of North America North of Mexico. 20+ vols. Jacquinia keyensis. New York and Oxford. Vol. 8, 2009. pp. 253-254. http://www.efloras.org/florataxon. aspx?flora_id=1\&taxon_id=250092184

Mullins, Stephen. "Moving joewood trees," The Palmetto, 1993. Orlando, Florida. Florida Native Plant Society.13(2): 8-9. http://fnps.org/assets/pdf/palmetto/mullins_stephen_ moving_joewood_trees_vol_13_no_2_summer_1993.pdf

Perkins, K.D., and W.W. Payne. 1980. Guide to the Poisonous and Irritant Plants of Florida. Circular 441. Gainesville: University of Florida Institute of Food and Agricultural Sciences.

The Angiosperm Phylogeny Group. 2003. "An update of the Angiosperm phylogeny group classification for the orders and families of flowering plants. APG II." Botanical Journal of the Linnean Society. 141: 399-436. http://onlinelibrary. wiley.com/doi/10.1046/j.1095-8339.2003.t01-1-00158.x/pdf

Tomlinson, P.B. 1986. The Biology of Trees Native to Tropical Florida. Massachusetts: Harvard University Printing Office.

Workman, R.W. 1980. Growing Native: Native plants for landscape use in Coastal South Florida. Sanibel, Florida: The Sanibel-Captiva Conservation Foundation, Inc.

Wunderlin, R.P., B.F. Hansen, A.R. Franck, and F.B. Essig. 2017. "Atlas of Florida Plants." Institute for Systematic Botany, University of South Florida, Tampa, Florida. http:// florida.plantatlas.usf.edu/browse/genus 